\title{
Synergetic Interaction of $P$ Solubilizer and $P$ Mobilizer on Yield and Economics of FCV Tobacco in KLS Region of Karnataka
}

\author{
T. M. Soumya ${ }^{1}$, M. K. Akshatha ${ }^{1 *}$ and G. J. Abhiram ${ }^{2}$ \\ ${ }^{1}$ Department of Agronomy, ZAHRS, UAHS, Shivamogga, India \\ ${ }^{2}$ AINP (T), ZAHRS, UAHS, Shivamogga, India \\ *Corresponding author
}

K e y w o r d s
P solubilizer, P
mobilizer, FCV
Tobacco, Yield and
B:C ratio

\section{A B S T R A C T}

\section{Introduction}

Flue Cured Virginia (FCV) tobacco is a type of tobacco mainly used as filler in cigarettes. It is obtained by flue curing of leaves in special structure called barn. FCV tobacco constitutes 30 per cent of total tobacco production in India and of which 80 per cent is exported. It has a significant role in Indian economy through foreign exchange and excise duty and thus forms an important commercial crop (Anonymous, 2020). It is cultivated as rainfed crop in KLS region of Karnataka and as irrigated in Andhra Pradesh. 
As leaf is the economic product indiscriminate use of fertilizer is quite common among the growers. Disproportionate use of NPK fertilizer not only affects the quality of the final produce and export potential but also environment adversely.

Among the major nutrients phosphate and potassium fertilizers are manufactured from mineral deposits and shrinkage of these deposits has raised the challenge of global food security (Smil, 2000). Phosphorus (P) is an essential plant nutrient and forms several structural units. It acts as energy currency by saving solar energy into ATP and memory unit by forming bonds in DNA and RNA strands. $\mathrm{P}$ is essentially required for root growth, photosynthesis, seed formation and early maturity (Shankar et al., 2013).

In soil $\mathrm{P}$ is found both mineral and organic forms. Most of the organic P (20 to 80\%) has been found to be inert. On an average, soil contains $400-1000 \mathrm{mg} \mathrm{kg}^{-1}$ of total $\mathrm{P}$, of which only $1.00-2.50$ per cent is in available form for plant uptake. Plant absorbs $\mathrm{P}$ either as $\mathrm{HPO}_{4}{ }^{-2}$ or $\mathrm{H}_{2} \mathrm{PO}_{4}{ }^{-}$and its concentration in soil solution is low. $\mathrm{P}$ availability is highly influenced by soil $\mathrm{pH}$, clay type and content, dominant cation and organic carbon content. Further, mineral $\mathrm{P}$ in the soil may become unavailable through fixation or adsorption by clay in soil. It may also become unavailable because of precipitation reactions with cations such as Ca-P in alkaline soil or Fe-P and Al-P in acidic soil. As a result, the concentration of mineral $\mathrm{P}$ in the soil solution rarely exceeds $0.1 \mathrm{mg} \mathrm{kg}^{-1}$.

Hence $\mathrm{P}$ fertilizer are periodically added and approximately 30 million tons of $P$ fertilizers (DAP and TSP) are used globally every year with an actual uptake efficiency of only 20 per cent. The remaining fraction is rapidly converted into insoluble complexes viz., insoluble iron/alluminum/calcium phosphate depending upon soil $\mathrm{pH}$ in the rhizosphere (Fernández et al., 2012). The use of chemical fertilizers can be reduced by exploiting bioinoculants or biofertlizer which are inexpensive and eco-friendly (Subhashini and Padmaja, 2011).

Phosphate solubilizing microbes (PSMs) are group of beneficial microorganisms capable of hydrolyzing organic and inorganic phosphorus compounds from insoluble compounds. The $\mathrm{P}$ solubilising ability of several strains of bacterial (Bacillus Pseudomonas and Azatobacter) and fungal (Penicillium and Aspergillus) species have been described in detail (He et al., 1997). These form integral part natural phosphorus cycle. Soil and seed inoculation with Phosphate Solubilizing Bacteria (PSB) improves solubilization of fixed soil phosphorus and of applied phosphates, resulting in higher crop yields (Bhatacharya and Jain, 2000).

Vesicular arbuscular mycorrhiza (VAM) - a root colonizing fungi stimulates plant growth and accelerates root development (Raminder et al., 2014). It forms association with more than 90 per cent of plant species and helps in mobilizing the available $\mathrm{P}$ by increasing root surface area and greater exploration of soil volume by its hyphal network (Suri et al., 2011). The synergic effect of $P$ solubilisation by PSB and P mobilization by VAM on crop productivity is often reported in literature (Zaidi and Khan, 2005; Patra et al., 2013). Even though these microbes are ubiquitous the phosphate solubilising ability varies from soil to soil or from one production system to another. Hence a study was taken with a objective to know the effect of P-solubilizer (Bacillus megaterium) and $\mathrm{P}$ mobilizer (Glomus mossae) and their combination with 100 and 75 per cent recommended phosphorus on the yield of Tobios- 6 variety of FCV Tobacco. 


\section{Materials and Methods}

The experiment was conducted at ZAHRS, Navile, Shivamogga during Kharif 2017 and 2018 with Randomized Complete Block Design. The soil of the experimental site (Table 1) was sandy loam with shallow depth, neutral in reaction $(\mathrm{pH}$ 6.70) with normal electrical conductivity $\left(0.136 \mathrm{dSm}^{-1}\right)$ and low in organic carbon $\left(4.90 \mathrm{~g} \mathrm{~kg}^{-1}\right)$. The soil was low in available nitrogen $\left(253.86 \mathrm{~kg} \mathrm{ha}^{-1}\right)$, high in available phosphorus (154.72 $\left.\mathrm{kg} \mathrm{ha}^{-1}\right)$, medium in available potassium $(220.14 \mathrm{~kg} \mathrm{ha}$ $\left.{ }^{1}\right)$.The total rainfall received during the crop growth period was lower than normal rainfall (Table 2) and per cent deviation of -3.97 (2017) and -6.74 (2018) was recorded.

Bacillus megaterium as $\mathrm{P}$ - solubilzer and Glomus mossae as $P$ - mobilizer was used in the study. Both biofertilizers were procured from Organic Farming Research Center, UAHS, Shivamogga. Standard Bacillus megaterium culture was obtained from UAS, GKVK, Bengaluru and mass production was carried out by following standard protocol. For VAM production, sterilized mixture of soil, sand and compost (2:2:1 ratio) was filled in pot. VAM culture (10\% solution) was inoculated and finger millet seeds were sown. The finger millet crop was maintained for 45 days. Latter VAM was isolated from rhizosphere of finger millet and used in the current study as VAM is not host specific but always host preference is there.

The experiment was replicated thrice with seven treatments viz., $\mathbf{T}_{\mathbf{1}}: 100 \% \mathrm{RDF} ; \mathbf{T}_{\mathbf{2}}$ : $100 \%$ RDF + P mobilizer @ $12.5 \mathrm{~kg} \mathrm{ha}^{-1} ; \mathbf{T}_{3}$ : $100 \% \mathrm{RDF}+\mathrm{P}$ solubilizer@12.5 kg ha ${ }^{-1}$; $\mathbf{T}_{4}: 100 \% \mathrm{RDF}+\mathrm{P}$ mobilizer @ $6.25 \mathrm{~kg} \mathrm{ha}$ ${ }^{1}+\mathrm{P}$ solubilizer@6.25 kg ha ${ }^{-1} ; \mathbf{T}_{5}: 75 \% \mathrm{RDP}$ + $100 \%$ RDNK + P mobilizer@12.5 kg ha ${ }^{1} ; \mathbf{T}_{\mathbf{6}}: 75 \% \mathrm{RDP}+100 \%$ RDNK + P solubilizer@12.5 kg ha ${ }^{-1}$ and $\mathbf{T}_{7}: 75 \% \mathrm{RDP}$ + $100 \%$ RDNK + P mobilizer@ 6.25 kg ha
${ }^{1}+\mathrm{P}$ solubilizer@6.25 $\mathrm{kg} \mathrm{ha}^{-1}$. Main field was thoroughly prepared by ploughing and FYM at the rate of $12.5 \mathrm{tha}^{-1}$ was applied 20 days before transplanting. Ridges were raised at $90 \mathrm{~cm}$ apart and planting point was marked at $60 \mathrm{~cm}$ distance.

Seedlings of 55 to 65 days were transplanted during July month. P- solubilzer and mobilizers were applied at the rate of $12.5 \mathrm{~kg}$ $\mathrm{ha}^{-1}$ and each at $6.25 \mathrm{~kg} \mathrm{ha}^{-1}$ in combination as per treatment requirement. P- solubilzer and mobilizer were mixed with FYM and applied around the seedling a day after planting. Basal dose of 50 per cent of $\mathrm{N}$ and $\mathrm{K}$ was applied through ammonium sulphate and SOP fertilizer. Entire dose of $\mathrm{P}$ was applied as basal through DAP as per treatment requirement. Except for the treatment crop was managed according to package of practices of the University. Green leaf and cured leaf yield from net plot were recorded at each picking for both the years and converted to $\mathrm{kg} \mathrm{ha}^{-1}$. Top grade equivalent was worked out after grading of conditioned leaves based on leaf position and colour. The economics was worked out for pooled yield data. Additional benefit cost ratio was worked out by considering additional expenditure made and additional returns obtained.

The experimental design was a randomized complete block design (RCBD), and the statistical analysis was done by the standard procedures suggested by Gomez and Gomez (1984).

\section{Results and Discussion}

\section{Green leaf yield, cured leaf yield and top grade equivalent}

The rate of $\mathrm{P}$ application and inoculation of $\mathrm{P}$ solubilizer and $\mathrm{P}$ mobilize either alone or in combination significantly influenced the green leaf yield, cured leaf yield and top 
grade equivalent (Table 3 ) during both the years as well as in pooled analysis. Treatment receiving 100 per cent $\mathrm{RDF}$ with application of P solubilizer and P mobilizer each @6.25 $\mathrm{kg} \mathrm{ha}^{-1}$ produced consistently and the highest green leaf yield (10795 kg ha-1) and cured leaf yield $\left(1060 \mathrm{~kg} \mathrm{ha}^{-1}\right)$. In pooled analysis application of $\mathrm{P}$ solubilizer and $\mathrm{P}$ mobilizer each@6.25 kg ha ${ }^{-1}$ along with 100 per cent RDF gave 9.12 per cent higher green leaf yield and 16.86 per cent higher cured leaf yield as compared to the 100 per cent RDF alone. When phosphate fertilizer is applied to soil all its water soluble $\mathrm{P}$ enters soil solution and readily forms sparingly soluble compound with aluminium, iron, calcium, etc. It is well recognized that the value of phosphate fertilizer depends primarily upon the release of $\mathrm{P}$ from these sparingly compounds. Application of $\mathrm{P}$ solubilizer and $\mathrm{P}$ mobilizer enhances the $\mathrm{P}$ availability to plants by solubilizing precipitated phosphates and mineralizing organic $\mathrm{P}$ in soil (Chen et al, 2006; Kang et al, 2002 and Pradhan and Sukla, 2005). Microbes influences soil fertility through different soil processes like assimilation, decomposition, mineralization and storage/release of nutrients.

Although the most prevalent reported benefit of biofertilizer is improved availability of nutrients, but there are increasing number of studies which describes other benefits. Increased level of phytohormones and other compounds viz., auxins, cytokinins, gibberellins, abscisic acid, ethylene and salicylic acid are commonly reported as result of biofertilizer application. Thus increased availability of these phytohormones greatly affects root growth, resulting in improvements in uptake of moisture and nutrients (Ardakani and Mafakheri, 2011).

Table.1 Initial soil properties of experimental site

\begin{tabular}{|l|c|}
\hline \multicolumn{1}{|c|}{ Parameters } & Values \\
\hline $\mathrm{pH}(1: 2.5)$ & 6.70 \\
\hline Electrical conductivity $\left(\mathrm{dS} \mathrm{m}{ }^{-1}\right.$ at $\left.25^{0} \mathrm{C}\right)$ & 0.136 \\
\hline Organic carbon $\left(\mathrm{g} \mathrm{kg}^{-1}\right)$ & 4.90 \\
\hline Available Nitrogen $\left(\mathrm{kg} \mathrm{ha}^{-1}\right)$ & 253.86 \\
\hline Available Phosphorus $\left(\mathrm{kg} \mathrm{ha}^{-1}\right)$ & 154.72 \\
\hline Available Potassium $\left(\mathrm{kg} \mathrm{ha}^{-1}\right)$ & 220.14 \\
\hline
\end{tabular}

Table.2 Year-wise normal and actual rainfall received $(\mathrm{mm})$ during crop period

\begin{tabular}{|c|c|c|c|c|c|c|}
\hline \multirow[t]{2}{*}{ Month } & \multicolumn{3}{|c|}{2017} & \multicolumn{3}{|c|}{2018} \\
\hline & $\begin{array}{c}\text { Normal } \\
\text { rainfall } \\
(\mathbf{m m})\end{array}$ & $\begin{array}{c}\text { Actual } \\
\text { rainfall } \\
(\mathbf{m m})\end{array}$ & Deviation & $\begin{array}{c}\text { Normal } \\
\text { rainfall } \\
(\mathbf{m m})\end{array}$ & $\begin{array}{c}\text { Actual } \\
\text { rainfall } \\
(\mathrm{mm})\end{array}$ & Deviation \\
\hline July & 201.9 (14) & $136.4(11)$ & -32.44 & $199.8(14)$ & $154.2(21)$ & -22.82 \\
\hline August & $139.2(14)$ & $156(11)$ & 12.07 & $139.7(14)$ & 174.2 (19) & 24.70 \\
\hline September & $102.7(7)$ & $186.6(14)$ & 81.69 & $105.4(7)$ & $82.4(5)$ & -21.82 \\
\hline October & $142(7)$ & $84.6(7)$ & -40.42 & $140.1(7)$ & $134.8(5)$ & -3.78 \\
\hline Total & $585.8(42)$ & $563.6(43)$ & -3.79 & $585(42)$ & $545.6(50)$ & -6.74 \\
\hline
\end{tabular}


Table.3 Effect of application of different rates of P, P-mobilizer and P-solubilizer on yield and top grade equivalent of FCV tobacco

\begin{tabular}{|c|c|c|c|c|c|c|c|c|c|}
\hline \multirow[t]{2}{*}{ Treatment } & \multicolumn{3}{|c|}{$\begin{array}{l}\text { Green leaf yield } \\
\qquad\left(\mathrm{kg} \mathrm{ha}^{-1}\right)\end{array}$} & \multicolumn{3}{|c|}{$\begin{array}{l}\text { Cured leaf yield } \\
\qquad\left(\mathrm{kg} \mathrm{ha}^{-1}\right)\end{array}$} & \multicolumn{3}{|c|}{$\begin{array}{l}\text { Top grade equivalent } \\
\qquad\left(\mathrm{kg} \mathrm{ha}^{-1}\right)\end{array}$} \\
\hline & 2017 & 2018 & Pooled & 2017 & 2018 & Pooled & 2017 & 2018 & Pooled \\
\hline $\mathrm{T}_{1}: \mathbf{1 0 0} \% \mathrm{RDF}$ & 10080 & 9708 & 9894 & 875 & 938 & 907 & 570 & 493 & 532 \\
\hline $\mathrm{T}_{2}: 100 \%$ RDF + P mobilizer @ $12.5 \mathrm{~kg} \mathrm{ha}^{-1}$ & 10544 & 10018 & 10281 & 1000 & 924 & 962 & 549 & 481 & 515 \\
\hline $\mathrm{T}_{3}: 100 \% \mathrm{RDF}+\mathrm{P}$ solubilizer @ $12.5 \mathrm{~kg} \mathrm{ha}^{-1}$ & 10523 & 10082 & 10303 & 971 & 933 & 952 & 454 & 488 & 471 \\
\hline $\begin{array}{l}\mathrm{T}_{4}: 100 \% \mathrm{RDF}+\mathrm{P} \text { mobilizer @ } 6.25 \mathrm{~kg} \mathrm{ha}^{-1}+ \\
\text { P solubilizer @ } 6.25 \mathrm{~kg} \mathrm{ha}^{-1}\end{array}$ & 10594 & 10995 & 10795 & 1078 & 1041 & 1060 & 485 & 574 & 529 \\
\hline $\begin{array}{l}\mathrm{T}_{5}: 75 \% \mathrm{RDP}+100 \% \mathrm{RDNK}+\mathrm{P} \text { mobilizer } \\
\text { @ } 12.5 \mathrm{~kg} \mathrm{ha}^{-1}\end{array}$ & 9659 & 9286 & 9472 & 990 & 857 & 924 & 558 & 535 & 546 \\
\hline $\begin{array}{l}\mathrm{T}_{6}: 75 \% \mathrm{RDP}+100 \% \mathrm{RDNK}+\text { P solubilizer } \\
\text { @ } 12.5 \mathrm{~kg} \mathrm{ha}^{-1}\end{array}$ & 8417 & 8928 & 8672 & 862 & 947 & 904 & 392 & 369 & 380 \\
\hline $\begin{array}{l}\mathrm{T}_{7}: 75 \% \mathrm{RDP}+100 \% \mathrm{RDNK}+\mathrm{P} \text { mobilizer } \\
@ 6.25 \mathrm{~kg} \mathrm{ha}^{-1}+\mathrm{P} \text { solubilizer @ } 6.25 \mathrm{~kg} \mathrm{ha}^{-1}\end{array}$ & 9779 & 10012 & 9896 & 956 & 989 & 972 & 555 & 573 & 564 \\
\hline SEm \pm & 343.65 & 342.88 & 283.75 & 39.86 & 32.76 & 29.13 & 31.08 & 31.26 & 28.65 \\
\hline CD at $5 \%$ & 1058.89 & 1056.51 & 874.33 & 122.82 & 100.96 & 89.77 & 95.77 & 96.32 & 88.28 \\
\hline
\end{tabular}

Note: $\quad$ P Mobilizer-Glomus mossae P Solubilizer- Bacillus megaterium 
Table.4 Effect P mobilizer and P solubilizer on benefit cost ratio of FCV Tobacco

\begin{tabular}{|c|c|c|c|c|c|}
\hline Treatment & $\begin{array}{l}\text { Cured leaf yield } \\
\quad\left(\mathrm{kg} \mathrm{ha}^{-1}\right)\end{array}$ & $\begin{array}{l}\text { Cost of } \\
\text { cultivation } \\
\left(\operatorname{Rs~ha}^{-1}\right)\end{array}$ & $\begin{array}{c}\text { Gross } \\
\text { return } \\
\text { (Rs ha-1) }\end{array}$ & $\begin{array}{l}\text { Net return } \\
\text { (Rs ha-1) }\end{array}$ & $\mathrm{B}: \mathrm{C}$ \\
\hline $\mathrm{T}_{1}: 100 \% \mathrm{RDF}$ & 907 & 115320 & 126980 & 11660 & 1.10 \\
\hline $\mathrm{T}_{2}: 100 \%$ RDF + P mobilizer @ $12.5 \mathrm{~kg} \mathrm{ha}^{-1}$ & 962 & 117070 & 134680 & 17610 & 1.15 \\
\hline $\mathrm{T}_{3}: 100 \% \mathrm{RDF}+\mathrm{P}$ solubilizer @ $12.5 \mathrm{~kg} \mathrm{ha}^{-1}$ & 952 & 117070 & 133280 & 16210 & 1.14 \\
\hline $\begin{array}{l}\mathrm{T}_{4}: 100 \% \mathrm{RDF}+\mathrm{P} \text { mobilizer @ } 6.25 \mathrm{~kg} \mathrm{ha}^{-1}+\mathrm{P} \\
\text { solubilizer @ } 6.25 \mathrm{~kg} \mathrm{ha}^{-1}\end{array}$ & 1060 & 117070 & 148400 & 31330 & 1.27 \\
\hline $\begin{array}{l}\mathrm{T}_{5}: 75 \% \mathrm{RDP}+100 \% \text { RDNK + P mobilizer @ } \\
12.5 \mathrm{~kg} \mathrm{ha}^{-1}\end{array}$ & 924 & 116820 & 129360 & 12540 & 1.11 \\
\hline $\begin{array}{l}\mathrm{T}_{6}: 75 \% \mathrm{RDP}+100 \% \mathrm{RDNK}+\text { P solubilizer @ } \\
12.5 \mathrm{~kg} \mathrm{ha}^{-1}\end{array}$ & 904 & 116820 & 126560 & 9740 & 1.08 \\
\hline $\begin{array}{l}\mathrm{T}_{7}: 75 \% \mathrm{RDP}+100 \% \mathrm{RDNK}+\mathrm{P} \text { mobilizer @ } \\
6.25 \mathrm{~kg} \mathrm{ha}^{-1}+\mathrm{P} \text { solubilizer @ } 6.25 \mathrm{~kg} \mathrm{ha}^{-1}\end{array}$ & 972 & 116820 & 136080 & 19260 & 1.16 \\
\hline
\end{tabular}

Note: P Mobilizer-Glomus mossae P Solubilizer- Bacillus megaterium

Market value: Rs. $140 \mathrm{~kg}^{-1}$

Cost of P-solubilizer: Rs. $100 \mathrm{~kg}^{-1}$

Cost of P-mobilizer: Rs. $100 \mathrm{~kg}^{-1}$ 
Table.5 Effect P mobilizer and P solubilizer on additional benefit cost ratio of FCV Tobacco

\begin{tabular}{|c|c|c|c|c|c|}
\hline Treatments & $\begin{array}{c}\text { Cured leaf } \\
\text { yield }\left(\mathrm{kg} \mathrm{ha}^{-1}\right)\end{array}$ & $\begin{array}{l}\text { Additional } \\
\text { yield over } \\
\text { check (kg) }\end{array}$ & $\begin{array}{c}\text { Additional } \\
\text { income } \\
\left(\mathrm{Rs} \mathrm{ha}^{-1}\right)\end{array}$ & $\begin{array}{c}\text { Additional } \\
\text { expenditure } \\
\text { (Rs) }\end{array}$ & $\begin{array}{c}\text { Additional } \\
\text { benefit } \\
\text { cost ratio }\end{array}$ \\
\hline $\mathrm{T}_{1}: \mathbf{1 0 0} \% \mathrm{RDF}$ & 907 & - & & - & - \\
\hline $\mathrm{T}_{2}: 100 \% \mathrm{RDF}+$ P mobilizer @ $12.5 \mathrm{~kg} \mathrm{ha}^{-1}$ & 962 & 55 & 7700 & 1750 & 4.4 \\
\hline $\mathrm{T}_{3}: 100 \% \mathrm{RDF}+\mathrm{P}$ solubilizer @ $12.5 \mathrm{~kg} \mathrm{ha}^{-1}$ & 952 & 45 & 6300 & 1750 & 3.6 \\
\hline $\begin{array}{l}\mathrm{T}_{4}: 100 \% \mathrm{RDF}+\mathrm{P} \text { mobilizer @ } 6.25 \mathrm{~kg} \mathrm{ha}^{-1}+\mathrm{P} \\
\text { solubilizer @ } 6.25 \mathrm{~kg} \mathrm{ha}^{-1}\end{array}$ & 1060 & 153 & 21420 & 1750 & 12.24 \\
\hline $\begin{array}{l}\mathrm{T}_{5}: 75 \% \mathrm{RDP}+100 \% \text { RDNK + P mobilizer @ } \\
12.5 \mathrm{~kg} \mathrm{ha}^{-1}\end{array}$ & 924 & 17 & 2380 & 1500 & 1.59 \\
\hline $\begin{array}{l}\mathrm{T}_{6}: 75 \% \mathrm{RDP}+100 \% \mathrm{RDNK}+\text { P solubilizer @ } \\
12.5 \mathrm{~kg} \mathrm{ha}^{-1}\end{array}$ & 904 & - & - & - & - \\
\hline $\begin{array}{l}T_{7}: 75 \% \text { RDP + } 100 \% \text { RDNK + P mobilizer @ } \\
6.25 \mathrm{~kg} \mathrm{ha}^{-1}+\text { P solubilizer @ } 6.25 \mathrm{~kg} \mathrm{ha}^{-1}\end{array}$ & 972 & 65 & 9100 & 1500 & 6.07 \\
\hline
\end{tabular}

Note: P Mobilizer-Glomus mossae P Solubilizer- Bacillus megaterium 
The beneficial effect of bio-agent inoculation on plant growth through root development, solubilisation minerals and plant water relationship were also reported by Poonia and Dhaka (2012). Further, in the present study application of $75 \%$ RDP $+100 \%$ RDNK along with application of $\mathrm{P}$ solubilizer and $\mathrm{P}$ mobilizer each@6.25 $\mathrm{kg} \mathrm{ha}^{-1}$ recorded on par cured leaf yield and TGA with the treatment receiving $100 \% \quad \mathrm{RDF}+\mathrm{P}$ solubilizer + P mobilize each@6.25 kg ha ${ }^{-1}$. Thus 25 per cent of fertilizer could be saved without yield reduction. This infers the balanced $\mathrm{P}$ nutrition through efficient solubilisation and mobilization of fixed $\mathrm{P}$ by microbes. Also pooled data showed that $75 \%$ RDP + $100 \%$ RDNK along with duel application of $\mathrm{P}$ solubilizer and $\mathrm{P}$ mobilizer each@6.25 kg ha ${ }^{-1}$ recorded highest TGE $\left(564 \mathrm{~kg} \mathrm{ha}^{-1}\right)$. Mehrvarz et al., (2008) observed that sole application of PSB increased the biological yield, while the application of the same bacteria along with mycorrhiza achieved the maximum grain weight.

Application of bio-agents alone or in combination with $\mathrm{P}$ fertilizer was $30-40$ per cent better in improving grain yield of wheat than $\mathrm{P}$ fertilizer alone and inoculation of bioagents in combination without $\mathrm{P}$ fertilizer improved grain yield up to 20 per cent as against sole $\mathrm{P}$ fertilization. The application of PSB and plant growth promoting rhizobacteria together could reduce 50 per cent of $\mathrm{P}$ fertilizer application without any significant decrease of crop yield (Sharma et al., 2013). The low yield of plants grown on the control treatments in the current study could be attributed to the disappearance of indigenous microbes, which are essential to improve nutrient bioavailability and uptake in the rhizosphere soil.

\section{Economics of PSB and VAM inoculation}

Perusal of data in the Table 4 indicate that the highest net returns (Rs. $31330 \mathrm{ha}^{-1}$ ) was observed with application of $100 \% \mathrm{RDF}+\mathrm{P}$ solubilizer@6.25 kg ha ${ }^{-1}+\mathrm{P}$ mobilizer @6.25 kg ha ${ }^{-1}$ followed by 75\% RDP + 100 $\%$ RDNK + P mobilizer@6.25 kg ha ${ }^{-1}+\mathrm{P}$ solubilizer@6.25 kg ha ${ }^{-1}$ (Rs. $19260 \mathrm{ha}^{-1}$ ). The B:C ratio ranged from 1.08 (75\% RDP + $100 \%$ RDNK + P solubilizer @ $\left.12.5 \mathrm{~kg} \mathrm{ha}^{-1}\right)$ to 1.27 (100\% RDF+ P solubilizer @ $6.25 \mathrm{~kg}$ $\mathrm{ha}^{-1}+\mathrm{P}$ mobilizer @6.25 $\left.\mathrm{kg} \mathrm{ha}^{-1}\right)$. The treatment receiving $100 \% \mathrm{RDF}+\mathrm{P}$ solubilizer@6.25 kg ha ${ }^{-1}+\mathrm{P}$ mobilizer @ $6.25 \mathrm{~kg} \mathrm{ha}^{-1}$ has recorded additional benefit cost ratio of 12.24 with an additional cost of Rs. $1750 \mathrm{ha}^{-1}$ (Table 5). The increases in monetary benefits and higher $\mathrm{B}: \mathrm{C}$ ratio with the application of $\mathrm{P}$ solubilizer and $\mathrm{P}$ mobilizer are purely due to increase in the yield. Use of bio-agents reduce the cost of cultivation by reducing fertilizer demand without comprising yield and hence gave higher B:C ratio. Similar observations were also reported in by Dadhich and Gupta (2001), Premsekhar and Rajashree (2009) and Singh et al., (2009).

The present study confirms the beneficial effect of $\mathrm{P}$ solubilizer and $\mathrm{P}$ mobilizer application in improving the yield of FCV tobacco. Application of $75 \%$ RDP $+100 \%$ $\mathrm{RDNK}+\mathrm{P}$ solubilizer and $\mathrm{P}$ mobilizer each at $6.25 \mathrm{~kg} \mathrm{ha}^{-1}$ recorded on par yield with $100 \%$ $\mathrm{RDF}$ alone and $100 \% \mathrm{RDF}+\mathrm{P}$ solubilizer and $\mathrm{P}$ mobilizer each at $6.25 \mathrm{~kg} \mathrm{ha}^{-1}$. Bioagents present in bio-fertilizer supports plant growth and help in realization of yield advantages. These are low cost natural inputs and can effectively reduce the synthetic fertilizer requirement. Thus efforts are needed to popularize $\mathrm{P}$ solubilizer and $\mathrm{P}$ mobilizer among farming community.

\section{References}

Anonymous, 2020, Tobacco in India: Importance and Policy challenges $3^{\text {rd }}$ edition, published by The Tobacco Institute of India. 
Ardakani, M and Mafakheri, S., 2011, Designing a sustainable agro-ecosystem for wheat (Triticum aestivum L.) production.J Appl Environ Biol Sci., 1:401-413.

Bhatacharya, P. and Jain, R.K. 2000. Phosphorous Solublizing Biofertilizers in the whirl pool of rock phosphatechallenges and opportunities. Fert. News, 45:45-52.

Chen, Y. P., Rekha, P. D., Arunshen, A. B., Lai, W. A. and Young, C. C., 2006, Phosphate solubilizing bacteria from subtropical soil and their tricalcium phosphate solubilizing abilities. Appl. Soil Ecol., 34:33-41.

Dadhich, L.K. and Gupta, A., 2001, Effect of phosphate solubilizing bacteria and phosphorus on the growth pattern of clusterbean. Annals of Biol., 17:107 110.

Fernández, L., Agaras, B., Zalba, P., Wall, L.G. and Valverde, C. 2012, Pseudomonas spp. isolates with high phosphate-mobilizing potential and root colonization properties from agricultural bulk soils under no till management. Biol. Fert. Soils, 48:763- 773.

Gomez, K. A. and Gomez, A. A., 1984, Statistical Procedures for Agricultural Research, John Wiley \& Sons, New York, NY, USA.

He, Z. L., Wu, J., O’Donnell, A. G. and Syers, J. K., 1997, Seasonal responses in microbial biomass carbon, phosphorus and sulphur in soils under pasture. Biol. Fertil. Soils, 24:421-428.

Kang, S. C., Hat, C. G., Lee, T. G. and Maheshwari, D. K., 2002, Solubilization of insoluble inorganic phosphates by a soil-inhabiting fungus Fomitopsis sp. PS 102. Curr. Sci., 82:439-442.

Mehrvarz, S., Chaichi, M. R. and Alikhani, H. A., 2008, Effects of phosphate solubilizing microorganisms and phosphorus chemical fertilizer on yield and yield components of Barley
(Hordeum vulgare L.), Am-Euras. J. Agric. Environ. Sci., 3:822-828.

Patra, P, Pati, B. K., Ghosh, G.K., Mura, S.S. and Saha, A., 2013, Effect of biofertilizers and sulphur on growth, yield, and oil content of hybrid Sunflower (Helianthus annuus. L) In a Typical Lateritic Soil. doi:10.4172/scientific reports, 2: 603.

Poonia, M. K. and Dhaka, B. L., 2012, Effect of phosphorus solublizing bacteria (PSB) on growth and yield in tomato. J.Hortl.Sci., 7: 104-107.

Pradhan, N. and Sukla, L. B. 2005. Solubilization of inorganic phosphate by fungi isolated from agriculture soil. African J. Biotechnol., 5:850-854.

Premsekhar, M. and. Rajashree, V., 2009, Influence of biofertilizers on the growth characters, yield attributes, yield and quality of tomato: Am.-Eurasian $J$. Sustain. Agric., 3:68-70

Raminder Kaur, Avtar Singh and Kang, J. S., 2014, Influence of different types of Mycorhizal fungi on crop productivity. Curr. Agric. Res. J., 2(1):51-54.

Shankar, T., Sivakumar, T., Asha, G., Sankaralingam, S. and Meenakshi Sundaram V., 2013, Effect of PSB on Growth and Development of Chilli and Maize Plants. World Appl. Sci. J., 26(5): 610-617.

Sharma, S. B., Sayyed, R. Z., Trivedi, M. H. and Gobi, T. A., 2013, Phosphate solubilizing microbes: sustainable approach for managing phosphorus deficiency in agricultural soils. Springer Plus, 2:587.

Singh, R., Singh, B. and Patidar, M., 2009, Effect of preceding crops and nutrient management on productivity of wheat (Triticum aestivum) based cropping system in arid region. Indian $J$. of Agron., 52: 267272.

Smil, V., 2000, Phosphorus in the Environment: Natural Flows and Human 
Interferences. Annu. Rev. Environ. Resour., 25:53-88.

Subhashini D. V and Padmaja K. 2011, Population dynamics and screening of phosphate-solubilizing bacteria isolated from tobacco (Nicotiana tabacum) based cropping systems. Indian J. of Agri. Sci. 81(8): 740-3.

Suri, V.K., and Choudary, K., Chander, G., Verma, T.S., Gupta, M. K. and Dutt, N., 2011, Improving phosphorus use through co-inoculation of vesicular arbuscular mycorrhizal fungi and phosphatesolubilizing bacteria in maize in an acidic alfisol. Commun Soil Sci., Plant Anl., 42: 2265-2273.

Zaidi, A. and Khan, M. S., 2005, Interactive effect of rhizotrophic microorganisms on growth, yield and nutrient uptake of wheat. J Plant Nutri, 28: 2079-2092.

\section{How to cite this article:}

Soumya, T.M., M. K. Akshatha and Abhiram, G. J. 2020. Synergetic Interaction of P Solubilizer and P Mobilizer on Yield and Economics of FCV Tobacco in KLS Region of Karnataka. Int.J.Curr.Microbiol.App.Sci. 9(10): 2374-2383.

doi: https://doi.org/10.20546/ijcmas.2020.910.284 